\title{
Proliferation response of lymphocytes in naturally BLV-infected cows with different phenotypes of blood leukocyte acid phosphatase
}

\begin{abstract}
In Black-and-White cattle, polymorphism of blood leukocyte acid phosphatase (AcP) is determined by a pair of autosomal alleles. Blood leukocyte AcP polymorphism exhibits a correlation with the white cell composition and the granulocyte metabolic efficiency in clinically healthy animals. The aim of the study was to determine the relationship between the AcP polymorphism and the lymphocyte proliferation response capacity in the first three months after calving of cows naturally-infected with bovine leukaemia virus. The study covered 61 Black-andWhite cows originating from one herd. The ELISA and PCR tests were used in the diagnosing BLV infections. Additionally agarose gel electrophoresis was used to determine the AcP polymorphism and the lymphocyte proliferation efficiency was determined based on the lymphoblastic transformation test using the isotope method. The obtained results suggest that the product of blood leukocyte acid phosphatase gene is likely to participate in the lymphocyte activation and proliferation and that there is an association between the biological function expression of the AcP gene product and the cows' susceptibility to infection with bovine leukaemia virus. Moreover, the results obtained seem to indicate that the correlation of both factors - the bovine leukaemia virus and the month of lactation - modifies the proliferation response of the phytohaemagglutinin unstimulated lymphocytes.
\end{abstract}

Key Words: acid phosphatase, ${ }^{3} \mathrm{H}$-thymidine, lymphoblastic transformation, PHA, polymorphism, interactions

\section{Zusammenfassung}

Titel der Arbeit: Profilerative Antwort der Lymphozyten bei Kühen mit anderen Phänotypen der sauren Phosphatase von weißen Blutkörperchen, die auf natürliche Weise mit dem Virus der Rinderleukose infiziert wurden

Der Polymorphismus der sauren Phosphatase (AcP) der Leukozyten bei Kühen der Schwarz-Weißen Rinderrasse ist durch das Paar autosomaler Allele bedingt. Er beweist die Verbindung mit der Populationsgrösse mancher Zellen des Systems der weißen Blutkörperchen und der metabolischen Leistungsfähigkeit der Granulozyten bei klinisch gesunden Tieren. Das Ziel der Untersuchungen bestand darin, die Abhängigkeiten zwischen dem Polymorphismus AcP und der Fähigkeit der Lymphozyte zu einer proliferativen Antwort in den ersten drei Monaten nach dem Auskalben, bei den auf natürliche Weise mit dem Virus der Rinderleukose infizierten Kühen, zu bestimmen. Es wurden 61 Kühe der Schwarz-Weißen Rasse aus einer Herde der Untersuchung unterzogen. Es wurden die Tests ELISA und PCR zwecks Diagnostizierung der BLV-Infizierungen eingesetzt. Für die Bestimmung des Polymorphismus AcP wurde eine Elektrophorese in Agar-Agar Gel angewendet. Die Leistungsfähigkeit der Lymphozyten wurde im Test einer blastischen Transformation der Lymphozyten unterzogen, bestimmt unter Anwendung einer Isotopenmethode.

Die erzielten Ergebnisse lassen eine Schlussfolgerung zu, dass sich das Genprodukt der sauren Phosphatese der Leukozyten höchstwahrscheinlich an der Aktivierung und Proliferation der Lymphozyten beteiligt und dass eine Verbindung zwischen der Expression der biologischen Funktion des Genproduktes AcP und der Anfälligkeit der Kühe gegen eine Infektion mit dem Virus der Rinderleukose besteht. Die erzielten Ergebnisse weisen darüberhinaus auch auf eine Mitwirkung von beiden Faktoren - dem Virus der Rinderleukose und dem Laktationsmonat bei der Modifizierung der proliferativen Antwort der nicht phytohaemagglutinin (PHA) stimmulierten Lymphozyten hin.

Schlüsselwörter: Blastische Transformation der Lymphozyten, ${ }^{3} \mathrm{H}$-Thymidin, Interaktionen, Polymorphismus, PHA, saure Phosphatase 
1. Introduction

Lymphocyte proliferation efficiency indicates the organism immunological condition (NOZOE et al., 2003) and it is determined based on the lymphocyte proliferation ability to respond to an antigen or a mitogen (THORN et al., 1981; JENSEN and CHRISTENSEN, 1981). Lymphocyte response to a mitogen in vitro produces similar effects to the immunological response caused by an antigen in vivo (MUSCOPLAST et al., 1974). These factors (mitogen or antigen) produce lymphocyte morphological and metabolic changes, which in turn, result in an increase in the blastic form pool ready for intensified immunological response (PEARSON et al., 1979). Glycoprotein gp51 of the bovine leukaemia viral envelope is the main antigen component powerfully stimulating lymphoblastic transformation (CALLEBAUT et al., 1993). Bovine leukaemic virus infects mainly B lymphocytes and evokes enzootic bovine leukaemia (EBL) (MIRSKY et al., 1996). In about 30\% of BLV-infected specimens, this disease can occur as a non-neoplastic (persistent lymphocytosis) accompanied by B lymphocyte polyclonal expansion. A mechanism of BLV-induced lymphocytosis has not yet been identified. The study results seem to indicate that susceptibility to BLV infections is to some extent determined by genetic predispositions (MIRSKY et al., 1998; KACZMARCZYK et al., 2004; KACZMARCZYK et al., 2005c). The correlations between the blood leukocyte acid phosphatase polymorphism and the number of some white cell types in clinically healthy cows suggest that acid phosphatase participates in their proliferation (KACZMARCZYK et al., 1989; KACZMARCZYK and TAUBE, 1990; KACZMARCZYK et al., 2004; KACZMARCZYK et al., 2005a).

The polymorphism of blood leukocyte acid phosphatase (AcP) is determined by a pair of autosomal alleles. The dominant gene $\mathrm{AcP}^{\mathrm{B}}$ controls the synthesis of isoenzyme $\mathrm{B}$, present in phenotype $\mathrm{AB}$. This phenotype is determined by two genotype groups: dominant homozygote $\mathrm{B} / \mathrm{B}$ and heterozygote $\mathrm{B} / \mathrm{b}$. The recessive gene $\mathrm{AcP}^{\mathrm{b}}$ in the homozygous genotype determines phenotype $\mathrm{A}$, in which isoenzyme $\mathrm{B}$ does not occur. Fraction A, which is encoded independently of a genetically determined AcP polymorphism, occurs in both phenotype groups (KACZMARCZYK and WALAWSKI, 1992).

Previous results suggesting the likely participation of blood leukocyte acid phosphatase in the peripheral blood lymphocyte proliferation highlight the need to determine the relationship between AcP polymorphism and lymphocyte capacity to proliferative response in the first three months after calving of cattle naturally-infected with bovine leukaemia virus.

2. Material and methods

Studies were performed on the population of 61 Black-and-White cows, aged 3-6 years, from a leukaemia-dominated herd. The animals were reared indoors in stalls under good zoohygienic conditions. The ELISA and PCR tests, as well as the previously described EBL diagnosis methods and principles, were applied in this study (KACZMARCZYK et al., 2004). The lymphocyte proliferation efficiency was determined based on the lymphoblastic transformation test using the isotope method. Phytohaemagglutinin (PHA) was used for stimulation of lymphoblastic transformation. Initial analyses were performed in the second half of the first month of lactation and were continued in the second and third month after calving. 
Polymorphism of blood leukocyte acid phosphatase was assayed by electrophoresis as described previously (KACZMARCZYK et al., 2004).

\section{1. $\quad$ Peripheral blood mononuclear cell preparation}

Peripheral blood mononuclear cells (PBMC) were isolated from the whole blood by density gradient centrifugation with Histopaque 1077, according to the procedure supplied by the manufacturer (Sigma Chemical Company, USA). In the MGG stained smears, lymphocytes amounted to at least $95 \%$ and their viability checked with $0.2 \%$ solution of Trypan blue was at least $93 \%$.

\section{2. $\quad$ Lymphocyte transformation assays}

Lymphoblastic transformation test was assayed as described previously (KACZMARCZYK et al., 2005b). The lymphocyte proliferation efficiency in the experimental cows was determined based on the spontaneous and PHA-induced lymphoblastic transformation rate and the stimulation index (SI = mean count per minute of cultures stimulated with $\mathrm{PHA} /$ mean count per minute of non-stimulated control cultures).

\subsection{Statistical analysis of data}

The results obtained were statistically analysed (mean, standard deviation, data distribution conformity test with the normal distribution curve). In the absence of conformity with this model, the values obtained were subjected to logarithmic transformation $\left(\log _{10}\right)$ and statistical calculations were made on logarithmic values. The statistical analysis did not include the stimulation index (SI) because this trait did not produce normal distribution even after logarithmic transformation of data. The impact of natural BLV infection (EBL+ and EBL- cows) on the lymphocyte proliferation capacity (single factor variance analysis) as well as the effect of acid phosphatase polymorphism in blood leukocytes (A phenotype and AB phenotype) (factor 1) and month of lactation (1, 2, 3 months after calving) (factor 2), as well as the impact of interactions between these factors on the level of the studied indices in the EBL-positive and EBL-negative cows (double factor variance analysis) were analysed. The general ANOVA/MANOVA for the factor systems and the POST HOC TEST and the Scheffe method were applied. Calculations were made with STATISTICA 6.0 computer software.

\section{Results}

The diagnostic tests found 43 cows (70.5\%) to be BLV- infected and 18 specimens (29.5\%) were diagnosed as EBL-negative. Within the EBL-positive cow group 11 specimens (25.6\%) were identified as phenotype A and 32 specimens $(74.4 \%)$ as phenotype $\mathrm{AB}$, while within the EBL-negative cow group, phenotype A was recorded in 5 cows (27.8\%), and phenotype AB in 13 cows (72.2\%).

While comparing the lymphoblastic transformation rate in the experimental cows, a significantly $(\mathrm{P} \leq 0.05$ ) higher values of the spontaneous lymphoblastic transformation test and somewhat higher values of the PHA-induced lymphoblastic transformation were found in the leukaemic cows than in the clinically healthy cows (Table). Moreover, the variability of the PHA-induced lymphoblastic transformation rate was greater than that of the spontaneous transformation (Table). 
In analysing the effect of acid phosphatase polymorphism on the lymphocyte immunological response capacity, the diversity of lymphocyte spontaneous proliferation rate in cows of different AcP phenotype was not recorded (Fig. 1). However, the rate of PHA-stimulated lymphoblastic transformation varied between these cows. A significantly higher $(\mathrm{P} \leq 0.01)$ PHA-stimulated lymphocyte reactivity was recorded in the $B L V$-positive $A$ phenotype cows in comparison to the $A B$ phenotype cows.

Table

Lymphocyte capacity to proliferate in the experimental cows $-{ }^{3}[\mathrm{H}]$ thymidine incorporation, $\log _{10}$ (Fähigkeit der Lymphozyten zur Proliferation bei den untersuchten Kühen $-{ }^{3}[\mathrm{H}]$ thymidine incorporation, $\left.\log _{10}\right)$

\begin{tabular}{ccccc}
\hline Indices & $\overline{\mathrm{x}}$ & $\mathrm{EBL}+$ & & $\overline{\mathrm{EBL}}$ \\
& $2.21^{\mathrm{a}}$ & $\mathrm{SD}$ & $\mathrm{x}$ & $\mathrm{SD}$ \\
\hline $\begin{array}{c}\text { Proliferation } \\
\text { unstimulated }\end{array}$ & 2.55 & 0.61 & $1.98^{\mathrm{a}}$ & 0.41 \\
$\begin{array}{c}\text { Proliferation PHA- } \\
\text { stimulated }\end{array}$ & 0.35 & 0.82 & 2.46 & 0.86 \\
${ }^{\mathrm{x}}$\begin{tabular}{l} 
Stimulation index \\
\hline
\end{tabular} & 0.68 & 0.49 & 0.75 \\
\hline
\end{tabular}

Mean values denoted with the same of small letters are significant at $\mathrm{P} \leq 0.05$.

${ }^{\mathrm{X}}$ Not statistically analysed (no conformity with the normal distribution model).
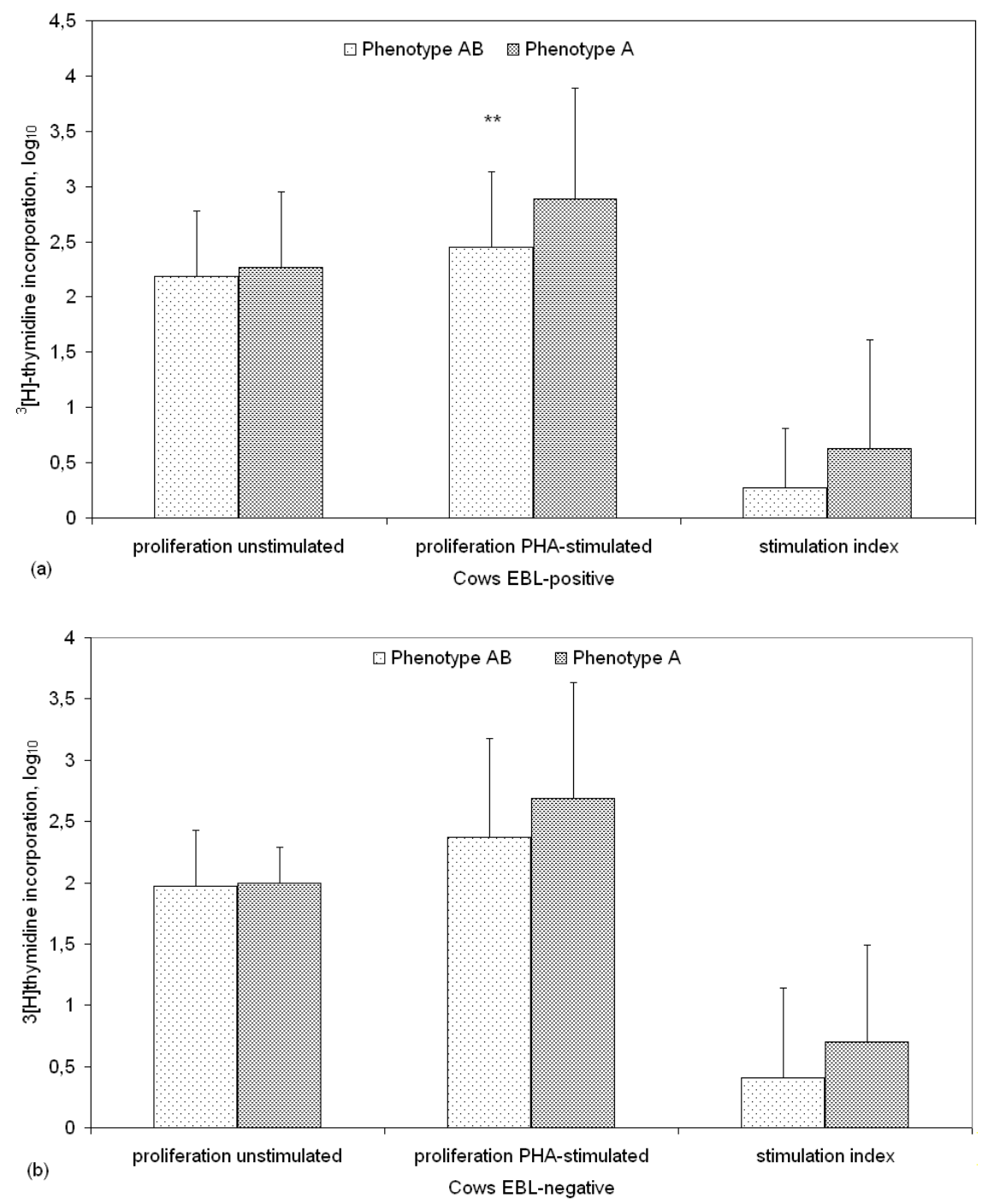

Fig. 1: Lymphocyte proliferation efficiency in cows with different AcP phenotypes (a) EBL-positive cows (b) EBL-negative cows (mean \pm SD) (Proliferative Leistungsfähigkeit der Lymphozyten bei den Kühen mit anderen Phänotypen AcP) (a) EBL-positive Kühe (b) EBL-negative Kühe ** $\mathrm{P} \leq 0.01$ 
Also, in the EBL-negative cows higher PHA-stimulated proliferation rate was exhibited by the lymphocytes of the A phenotype cows, however, the differences were statistically insignificant $(\mathrm{P}=0.22)$. Moreover, the lymphocytes in the $\mathrm{AB}$ phenotype cows showed a similar PHA stimulation rate in both groups (EBL-positive - 2.45; EBL-negative - 2.37), while the lymphocyte response to this mitogen in the A phenotype cows varied (EBL-positive - 2.89; EBL-negative - 2.69) (Fig. 1a, b). However, the observed differences were not statistically significant. Moreover, the A phenotype cows exhibited higher stimulation index rates regardless of the cows' health state, however, these values were not statistically analysed (Fig. 1).
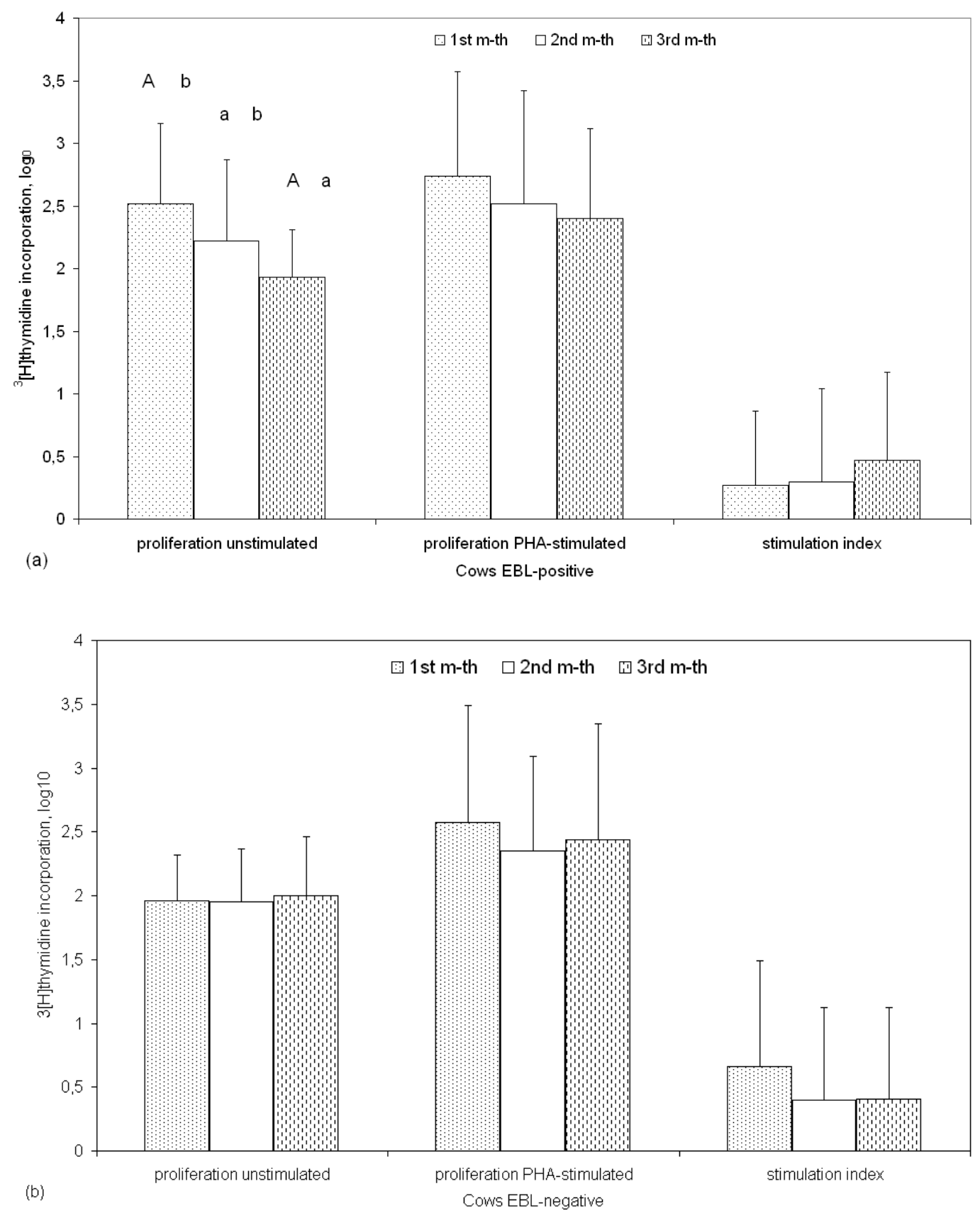

Fig. 2: Lymphocyte proliferation response in cows in particular months of lactation (a) EBL-positive cows (b) EBL-negative cows (mean \pm SD) (Proliferative Antwort der Lymphozyten bei Kühen in den einzelnen Laktationsmonaten. (a) EBL-positive Kühe (b) EBL-negative Kühe)

Mean values denoted the same of small letter are statistically different at $\mathrm{P} \leq 0.05$

Mean values denoted the same of capital letter are statistically different at $\mathrm{P} \leq 0.01$ 
In analysing the diversity of lymphocyte proliferation efficiency in cows in the first months after calving, certain differences in changes in the cows' health states were recorded (Fig. 2).

A significant $(\mathrm{P} \leq 0.01)$ decrease in the spontaneous lymphoblastic transformation rate and a regular but not statistically significant $(\mathrm{P}=0.28)$ decrease in the PHA-stimulated lymphoblastic transformation rate in subsequent months after calving was recorded in the EBL-positive cows. The lymphocyte spontaneous proliferation was lower in the EBL-negative than in the EBL+ cows, however, it was very even. On the other hand, the PHA-stimulated lymphocyte proliferation was maintained at a level similar to that recorded for the leukaemic cows, however, the differences in the analysed months were small and statistically insignificant (Fig. 2b).

\section{$4 . \quad$ Discussion}

The assessment of the cellular immunity state is most frequently done based on a lymphoblastic transformation test which permits the determination of the proliferation efficiency of antigen- or mitogen-stimulated lymphocytes (JENSEN and CHRISTENSEN, 1981). The amount of the $\left[{ }^{3} \mathrm{H}\right]$ thymidine incorporated to DNA during cell division is a very sensitive marker of the ability of cell to divide (CHAROENPPORNSOOK et al., 1998). The $\left[{ }^{3} \mathrm{H}\right]$ thymidine uptake by peripheral blood lymphocytes is greater in mitogen-stimulated lymphocytes than in those unstimulated (QUADE and ROTH, 1999; KACZMARCZYK et al., 2005b). A similar regularity was found in the present study (Table). In other hand, blastogenic activity of unstimulated lymphocytes was significantly higher in the EBL-positive cows than in the clinically healthy animals (Table). It is postulated that the spontaneous lymphocyte proliferation in the BLV-infected PL cattle is mainly caused by B lymphocyte proliferation, which do not take part in viral antigen expression and to a lesser extent by a participation of proliferating $\mathrm{T}$ lymphocytes (STONE et al., 2000). The progression of BLV infection to PL is likely to be linked with a reduced expression of classical Th1 and Th2 cytokines by CD4+ T cells, which can indicate aberrant Th regulation in sublinically infected animals (AMILLS et al., 2002). A significant role in the spontaneous lymphocyte proliferation is ascribed to interleukine 2 (IL-2), released mainly by Th1 lymphocytes (CD4+) activated by viral proteins (STONE et al., 1995, 2000; TRUEBLOOD et al., 1998). It is postulated that a positive feedback loop between IL-2 and viral expression and the increased T-lymphocyte expression of IL-2 in BLV-infected cows contributes to development and/or maintenance of persistent B lymphocytosis (STONE et al., 1995; TRUEBLOOD et al., 1998).

In the present study, a relationship between the polymorphism of acid phosphatase of blood leukocytes and a diversity in lymphocyte response to a mitogen connected with the BLV-infection was observed (Fig. 1). The proliferation efficiency of the PHAstimulated lymphocytes is greater in A phenotype specimens than in the AB phenotype animals, however, only the differences between the phenotypes found in the BLVinfected animals were statistically significant. A diversified lymphocyte response to PHA between different AcP phenotypes cows seems to indicate a greater susceptibility of the cells isolated from the A phenotype cows than the lymphocytes originating from the $\mathrm{AB}$ phenotype animals. These differences were particularly explicit in the BLVinfected animals (Fig. 1a). Exogenic mitogens affecting $\mathrm{T}$ lymphocytes (e.g. phytohaemagglutinin) increased BLV expression in infected cells (CORNIL et al., 
1988). It is postulated that an increase in the provirus expression is caused by a PHA induced protein described as BLV-transcription stimulatory (BTS) protein (CHATTERJEE et al., 1985). It is likely that the first step of BLV stimulation is the result of PHA interaction with a membrane receptor of $B$ lymphocytes (CHATTERJEE et al., 1985; CHATTERJEE and GUPTA, 1989), however, the mechanism that initiates this reaction and BTS synthesis has not been identified yet. Cytokines secreted by T lymphocytes, as well as cell-cell interactions participate in the B lymphocyte stimulation by PHA (QUADE and ROTH, 1999).

The results of the previous studies found a relationship between the blood leukocyte AcP polymorphism and the diversity of peripheral blood lymphocyte profile (KACZMARCZYK et al., 2004). In the A phenotype cows, a significantly higher number of CD19+ B lymphocytes as well as lower numbers of CD2+ and CD8+ T lymphocytes were recorded, compared with the AB phenotype cows. Moreover, an interaction between the AcP polymorphism and BLV infection had an effect on the number and percentage of CD19+ B lymphocytes. It seems that the stronger lymphocyte response to PHA observed in the present study in recessive homozygotes (A phenotype) may indicate a greater ability of these B lymphocytes to activate and, in the case of BLV infection, uncontrollably proliferate. The presented hypotheses need to be verified in further, more detailed studies.

Assuming that PHA induced proteins cause an increase in the expression of viral genome (CHATTERJEE et al., 1985) and the first step of BLV stimulation is the result of PHA interaction with a membrane receptor of B lymphocytes (CHATTERJEE et al., 1985; CHATTERJEE and GUPTA, 1989), it seems that a molecule identified by mouse IgM anti-bovine B-B2 antibodies similar to the human CD19 (WINNICKA et al., 1999) could be such a receptor. The CD19 molecule is recognised as a key component of an intercellular pathway responsible for B lymphocyte activation (FUJIMOTO et al., 1999). In addition, it participates in the co-stimulation of B lymphocyte activated by a specific antigen or mitogen in the first step of cellular activation (FUJIMOTO et al., 1998). A similar role is played by CD2 molecule towards T lymphocytes (DANIELAN et al., 1992). Evoking a positive signal of lymphocyte activation requires activation of co-stimulating molecules. Otherwise, the cell undergoes anergy (loses the activation ability). The results of the previous (KACZMARCZYK et al., 2004) and the present study seem to indicate possible blood leukocyte AcP gene product-mediated signalling from B lymphocyte surface receptor to the inner part of a cell. The AcP participation in the activation and proliferation of lymphocytes may also be connected with the expression of the enzymatic function of acid phosphatase in the lymphocytes of BLV-infected or clinically healthy cows with different AcP phenotypes (interaction between AcP polymorphism and leukaemia) (KACZMARCZYK et al., 2005c). Significantly higher activity of this enzyme was recorded in lymphocytes of the clinically healthy A phenotype animals than in the lymphocytes of AB phenotype animals. This may impair the dephosphorylation of important elements (e.g. protein kinase) which participate in signal transmission from a membrane receptor complex into the inner part of the cell and consequently decrease the threshold of B lymphocyte activation.

Proteins undergoing a reversible phosphorylation participate in numerous biological processes in a cell. The phosphorylation degree of these proteins is regulated by opposed processes catalysed by kinases and protein phosphatases, however, the 
mechanisms of this regulation have not yet been thoroughly researched. In recent years an increasing interest in protein phosphatases has been observed. This was caused by a discovery of their significant role in tumour supression and in the regulation of cellular cycle (LI and DIXON, 2000; WEN et al., 2001). Some of them are multifunctional (DISSING et al., 1991; KIMBERLEY et al., 1992).

The results of the previous and the present study seem to indicate that the product of blood leukocyte acid phosphatase gene is likely to participate in lymphocyte activation and proliferation and seems to confirm that there is an association between the biological function expression of the AcP gene product and the cows' susceptibility to natural infection with the bovine leukaemia virus.

The ability of lymphocytes to form an immunological response, which is recorded in the first three months of lactation, seemed to be largely determined by diagnosed BLV infection (Fig. 2). A regular decrease in the spontaneous blastogenesis rate, as well as similar, but statistically insignificant, diversification of lymphocyte response to PHA was observed in the EBL+ cows (Fig. 2a).

It is postulated that during the perinatal period, the diminished lymphocyte functions and the delayed host immune responsiveness occur which are caused by an increase in the level of immunosupressive factors (e.g. steroids, pregnancy zone protein, early pregnancy factor, etc.) (WEINBERG, 1984). A reduced proliferation response of lymphoid cells to antigen or a mitogen was observed in vitro (SHAFER-WEAVER et al., 1996) as well as a decreased ability of lymphocytes to produce antibodies and of cytokine secretion (SORDILLO et al., 1991; NAGAHATA et al., 1992). The disturbances in immunological functions occurring for a short period before and after delivery may favour new infections and the spreading of microorganisms in the body (SHAFER-WEAVER et al., 1996). BLV infections in leukaemic herds are also more frequent in this period. In BLV+ cows, the synthesis of anti-BLV antibodies begins between 2 and 8 week after infection (BURNY et al., 1980) and the antibodies in vitro inhibit spontaneous proliferation of peripheral blood mononuclear cells (PBMC) (THORN et al., 1981; TRUEBLOOD et al., 1998). The regular decrease in the PBMC proliferation abilities observed in the EBL+ cows in the first three months of lactation seems to be caused by new BLV infections in the perinatal period and by the development of an immunological response by the host. Interactions between $\mathrm{B}$ and $\mathrm{T}$ lymphocytes may contribute to an increase in antibody response to cell-dependent antigens (ISAACSON et al., 1998) and have an effect on the lymphocyte spontaneous proliferation in EBL+ cows. In clinically healthy cows, a similar ability of lymphocytes to spontaneous lymphoblastic transformation and a little differentiation in cell response to PHA was observed throughout the entire trimester of lactation (Fig. 2), which seems to confirm our hypothesis. The results of the present study do not confirm the reduction of lymphocyte proliferation activity in the first month of lactation, only previously cited results of the author have indicated a significant decrease in the percentage of CD19+ B lymphocytes in clinically healthy cows (KACZMARCZYK et al., 2004). The obtained results could have been caused by the research start date which was in the middle of the first month of lactation. The possibility of comparison and interpretation of the results is largely hindered by the lack of publications presenting the dynamics of the changes in lymphocyte proliferation efficiency in clinically healthy cows in the subsequent weeks or months of the first trimester of lactation. 
The wide variability in both the spontaneous and PHA-induced blastogenesis rate was recorded in the present experiment as well as by other authors (THODE-JENSEN and CHRISENSEN, 1981; FISCUS et al., 1983; TIERNEY et al., 1997; FLAMING et al., 1997). A possible polygenic nature could explain a wide variability of this trait.

The obtained results suggest that the product of blood leukocyte acid phosphatase gene is likely to participate in the lymphocyte activation and proliferation and that there is an association between the biological function expression of the AcP gene product and the cows' susceptibility to infection with the bovine leukaemia virus. Moreover, the results obtained seem to indicate that the synergy of both factors - the bovine leukaemia virus and the month of lactation modifies the proliferation response of the phytohaemagglutinin unstimulated lymphocytes.

The obtained results encourage further more detailed studies into the properties and the role of the blood leukocyte AcP gene product in the pathogenesis of enzootic bovine leukaemia.

\section{References}

AMILLS, M.; RAMIYA, V.; NORIMINE, J.; OLMSTEAD, C.A.; LEWIN, H.A.: Reduced IL2 and IL-4 mRNA expression in CD4+ T cells from bovine leukemia virus-infected cows with persistent lymphocytosis. Virol 304 (2002), 1-9

BURNY, A.; BRUCK, C.; CHANTRENNE, H.: Bovine leukemia virus: molecular biology and epidemiology. Raven Press, New York, 1980

CALLEBAUT, I.; VONECHE, V.; MAGER, A.; FUMIERE, O.; KRCHNAK, V.; MERZA, M.; ZAVADA, J.; MAMMERICKX, M.; BURNY, A.; PORTETELLE, D.:

Mapping of B-neutralizing and T-helper cell epitopes on the bovine leukemia virus external glycoprotein gp 51. J Virol. 67 (1993), 5321-5327

CHAROENPPORNSOOK, K.; FITZPATRIC,K J.L.; SMITH, J.E.:

The effects of four mycotoxins on the mitogen stimulated proliferation of bovine peripheral blood mononuclear cells in vitro. Mycopathologia 143 (1998), 105-111

CHATTERJEE, I.; GUPTA, P.:

Binding of phytohemagglutinin to bovine B lymphocytes and its role in stimulation of expression of bovine leukemia virus genome. Indian J. Exp. Biology 27 (1989), 430-436

CHATTERJEE, I.; GUPTA, P.; KASHMIRI, S.V.S.; FERRER J.F.:

Phytohemagglutinin activation of the transcription of the bovine leukemia virus genome requires de novo protein synthesis. J. Virol. 54 (1985), 860-863

CORNIL, L.; DELON, P.; PARODI, A.; LEVY, D.:

T-B cell cooperation for bovine leukemia virus expression in ovine lymphocytes. Leukemia 2 (1988) 313-317

DANIELIAN, S.; ALCOVER, A.; POLISSARD, L.; STEFANESCU, M.; ACUTO, O.; FISCHER, S.;

FAGARD, R.; BOTH T.:

Cell receptor (TcR)-CD3 complex and CD2 increase the tyrosine kinase. Eur. J. Immunol. 22 (1992), 2915-2921

DISSING, J.; JOHNSEN, A.H.; SENSABAUGH, G.F.:

Human red cell acid phosphatase (ACP1). The amino acid sequence of the two isozymes Bf and Bs encoded by the ACP1*B allele. J. Biol. Chem. 266 (1991), 20619-20625

FISCUS, S.A.; DE MARTINI, J.C.; PEARSON, L.D.:

Variation in mitogen-induced ovine lymphocyte blastogenesis. Vet. Immunol. Immunopathol. 3, (1983), 345-359

FLAMING, K. P.; FRANK, D. E.; CARPENTER, S., ROTH, J. A.:

Longitudinal studies of immune function in cattle experimentally infected with bovine immunodeficiency - like virus and/or bovine leukemia virus. Vet. Immunol. Immunopathol. 56, (1997), 27-38

FUJIMOTO, M.; POE J. C.; INAOKI, M.; TEDDER, T. F.:

CD19 regulates B lymphocyte responses to transmembrane signals. Semin. Immunol. 10 (1998), 267277

FUJIMOTO, M.; POE J.C.; JANSEN, P.J.; SATO, S.; TEDDER, T.F.: 
CD19 amplifies B lymphocyte signal transduction by regulating Src-family protein tyrosine kinase activation. J. Immmunol. 162 (1999), 7088-7094

ISAACSON, J. A.; FLAMING, K. P.; ROTH, J. A.:

Effects of long-term infection with bovine immunodeficiency virus and/or bovine leukemia virus on antibody and lymphocyte proliferative responses in cattle. Vet Immnuol Immnunopathol, 64 (1998), 249-266

JENSEN, P.T., CHRISTENSEN, K.:

In vitro evaluation of porcine lymphocyte response to phytohaemagglutinin using a modified "whole blood” technique. Vet. Immunol. Immunopathol. 2 (1981), 121-132

KACZMARCZYK, E.; AMIELAŃCZYK, W.; WALAWSKI, K.; SOWIŃSKI, G.: Polymorphism of acid phosphatase in the leukocytes of peripheral blood and level of hematological and immunological indices in young bulls of different ages. (in polish), Pol. Arch. Wet. 29 (1989), 107-123

KACZMARCZYK, E.; TAUBE, K.:

The influence of acid phosphatase polymorphism of blood leucocytes on selected haematological and immunological indices in young cattle. Genet. Pol. 31 (1990), 245-250

KACZMARCZYK, E.; BOJAROJĆ-NOSOWICZ, B.; FIEDOROWICZ, A.; DEMIANOWICZ W.:

Polymorphism of blood leukocyte acid phosphatase and the profile of peripheral blood lymphocytes in the first of lactation trimester of cows naturally-infected with bovine leukaemia virus. Arch. Tierz., Dummerstorf 47 (2004), 415-430

KACZMARCZYK, E.; BOJAROJĆ-NOSOWICZ, B.; FIEDOROWICZ, A.:

Polymorphism of blood leukocytes acid phosphatase and haematological indices during the first months after calving in cows naturally-infected with the bovine leukaemia virus. Bull Vet. Inst. Pulawy 49 (2005a), 15-21

KACZMARCZYK, E.; FIEDOROWICZ, A.; BOJAROJĆ-NOSOWICZ, B.; ŚWIĘCICKA-GRABOWSKA M.; JAKUBOWSKI K.:

Lymphocyte proliferation efficiency in the first months of life of heifer calves naturally infected with bovine leukaemia virus. Bull. Vet. Inst. Pulawy 49 (2005b), 9-14

KACZMARCZYK, E.; BOJAROJĆ-NOSOWICZ, B.; FIEDOROWICZ, A.: Leukocyte acid phosphatase and metabolic efficiency of phagocytes in the first lactation trimester of cows from a leukaemic herd. J. Appl. Genetics 46 (2005c), 59-67

KACZMARCZYK, E.; WALAWSKI, K.:

Genetic determination of acid phosphatase polymorphism of blood leucocytes in cattle. Genet. Pol., 33 (1992), 125-129

KIMBERLEY, R. F.; SHEKELS, L. L.; BERNLOHR, D. A.:

Analysis of the ACP1 gene product: classification as an FMN phosphatase. Biochem. Biophys. Res. Comm. 199 (1992), 1598-1605

LI, L.; DIXON J.E.:

Form, function, and regulation of protein tyrosine phosphatases and their involvement in human diseases. Semin. Immunol. 12 (2000), 75-84

MIRSKY, M.L.; OLMSTED, C.A.; DA, Y., LEWIN, H.A.:

The prevalence of proviral bovine leukemia virus in peripheral blood mononuclear cells at two subclinical stages of infection. J. Virol. 70 (1996), 2178-2183

MIRSKY, M.L.; OLMSTED, C.A.; DA, Y.; LEWIN, H.A.:

Reduced bovine leukemia virus load in genetically resistant cattle. Anim. Genet. 29 (1998), 245-252

MUSCOPLAST, C.C.; ALHAJI, I.; JOHNSON, D.W.; POMEROY, K.A.; OLSON, J.M.; LARSON, V.L.;

STEVENSEN, D.K.:

Characteristics of lymphocyte responses to phytomitogens: Comparison of responses to lymphocytes from normal and lymphocytotic cows. Am. J. Vet. Res. 35 (1974), 1053-1055

NAGAHATA ,H.; OGAWA, A.; SANADA, Y.; NODA, H.; YAMAMOTA, S.:

Peripartum changes in antibody producing capability of lymphocytes from dairy cows. Vet. Q. 14 (1992), 39-40

NOZOE, T.; KORENAGA, D.; OHGA, T.; FUTATSUGI, M.; MAEHARA, Y.:

Suppression of the phytohemagglutinin response to lymphocytes is an independent prognosticator in patients with squamous cell carcinoma of the esophagus. Ann. Thorac. Surg. 76 (2003), 260-265

PEARSON, T.W.; ROELANTS, G.E.; LUNDIN, L.B.;MAYOR-WITHEY, K.S.:

The bovine lymphoid system: binding and stimulation of peripheral blood lymphocytes by lectins. J. Immunol. Methods. 26 (1979), 271-281

QUADE, M.J.; ROTH, J.A.:

Dual-color flow cytometric analysis of phenotype, activation marker expression, and proliferation of mitogen-stimulated bovine lymphocyte subsets. Vet. Immunol. Immunopath. 67 (1999), 33-45

SHAFER-WEAVER, K.A.; PIGHETTI, G.M.; SORDILLO, L.M.: 
Diminished mammary gland lymphocyte functions parallel shifts in trafficking patterns during the postpartum period. Proc. Soc. Exp. Biol. Med. 212 (1996), 271-279

SORDILLO, L.M.; REDMOND, M.; CAMPOS, M.; WARREN, L.; BABIUK, L.A.:

Cytokine activity in bovine mammary gland secretions during the periparturient period. Can. J. Vet. Res. 55 (1991), 298-301

STONE, D.M.; HOF, A.J.; DAVIS, W.C.:

Up-regulation of IL-2 receptor $\alpha$ and MHC class II expression on lymphocyte subpopulations from bovine leukemia virus infected lymphocytotic cows. Vet. Imm. Immunopath. 48 (1995), 65-76

STONE, D.M.; NORTON, L.K.; DAVIS, W.C.:

Spontaneously proliferating lymphocytes from bovine leukaemia virus-infected, lymphocytotic cattle are not the virus-expressing lymphocytes, as these cells are delayed in $G_{0} / G_{1}$ of the cell cycle and are spared from apoptosis. J. Gen. Virol. 81 (2000), 971-981

THORN, R.M.; GUPTA, P.; KENYON, S.J.; FERRER, J.F.:

Evidence that the spontaneous blastogenesis of lymphocytes from bovine leukemia virus-infected cattle is viral antigen specific. Infect Immun. 34 (1981), 84-89

TRUEBLOOD, E.S.; BROWN, W.C.; PALMER, G.H.; DAVIS, W.C.; STONE, D.M.; MCELWAIN, T.F.:

B-lymphocyte proliferation during bovine leukemia virus-induced persistent lymphocytosis is enhanced by T-lymphocyte derived Interleukin-2. J. Virol. 4 (1998), 3169-3177

THODE-JENSEN, P.; CHRISTENSEN, K.:

Genetic studies on the in vitro PHA transformation of porcine blood lymphocytes. Vet. Immunol. Immunopathol. 2 (1981), 133-143

TIERNEY T.J.; SIMPSON-MORGAN M.W.:

The proliferative response of lymphocytes from foetal calves and adult cattle. Vet. Immunol. Immunopathol. 59 (1997), 49-64

WINNICKA, A.; KLUCIŃSKI, W.; KAWIAK, J.; HOSER, G.; RYNIEWICZ, Z.; SIKORA, J.; SITARSKA, E.; BAŃKOWSKI, R.:

Lymphocyte subpopulations, null cells and MHC II positive cells in peripheral blood of goats at

WEINBERG, E.D.: different ages. Small Rum. Res. 33 (1999), 247-253

Pregnancy-associated depression of cell-mediated immunity. Rev. Infect. Dis. 6 (1984), 814-831

WEN, S.; STOLAROV, J.; MYERS, M.P.; DONG, SU J.; WIGLER, M.H.; TONKS, N.; DURDEN D.L.: PTEN controls tumour-induced angionenesis. PNAS 98 (2001), 4622-4627

Received: 2005-02-21

Accepted: 2006-03-16

Corresponding Author

Dr. habil. EWA KACZMARCZYK

University of Warmia and Mazury in Olsztyn,

Department of Animal Genetics,

ul. Oczapowskiego 5, 10-719 Olsztyn,

Poland

E-Mail: ewagen@moskit.uwm.edu.pl 